\title{
PERANCANGAN BUKU BERGAMBAR INTERAKTIF LIFT A FLAP UNTUK MEMBANTU KETERLAMBATAN WICARA ANAK ASD (AUTISM SPECTRUM DISORDER) DI RUMAH
}

\author{
Mohamad Dzikri Alhamdi ${ }^{1}$, Hafiz Aziz Ahmad² dan Riama Maslan \\ Sihombing ${ }^{3}$ \\ 1,2,3Fakultas Seni Rupa dan Desain- Institut Teknologi Bandung \\ Jl Ganesha 10 Bandung - Indonesia \\ Email: elghirniq@gmail.com, hafizsan@yahoo.com, riafleur2@gmail.com
}

\begin{abstract}
Abstrak: Autism Spectrum Disorder (ASD) merupakan gangguan psikologi pada anak yang memengaruhi kelainan pada perkembangan perpasif otak yang mengakibatkan terganggunya kemampuan bahasa dan perilaku. Hal tersebut mendasari bagi lembaga pendidikan khusus seperti Lembaga Pendidikan Autisma Prananda Bandung (LPAPB) untuk merancang program berbasis media grafis sebagai strategi untuk membantu meningkatkan kemampuan berkomunikasi ekspresif anak ASD di lembaga dan dirumah dengan metode Home Based Program, yang mendasari adalah karena kesulitannya dalam berlatih pembendaharaan kosakata dasar sehingga mengakibatkan maksud dan keinginannya sulit dipahami. Penelitian ini bertujuan untuk mengidentifikasi kebutuhan sarana pembelajaran anak ASD High Function untuk mempelajari kosakata, kategori kosakata dan merangkai kata melalui Home Based Program di LPAPB. Metode perancangan ini menggunakan Human Centered Design (HCD) melalui tahapan Observation, Idea Generation, Prototype dan Test yang mengadopsi metode Double Diamond dengan alat uji hasil perancangan yang bernama Human Centered Design Toolkit yang mengutamakan aspek kebutuhan, kemampuan dan perilaku pengguna sebagai dasar perancangan dengan efektif. Hasil penelitian ini berupa buku bergambar interaktif lift $a$ flap sebagai alternatif media grafis dengan implementasi konten pengembangkan kemampuan pembendaharaan kosakata, pengategorian serta perangkaian kata melalui Home Based Program. Hasil pengujian menunjukan; buku bergambar interaktif lift a flap dapat menjadi media grafis alternatif yang efektif, sebagai upaya pengembangan media pembelajaran khusus anak ASD.
\end{abstract}

Kata Kunci: ASD High Function, home based program, buku bergambar interaktif lift a flap, kosakata.

Abstract: ASD (Autism Spectrum Disorder) is a child psychological disorder effects abnormalities in the development of cervical dysfunction which results in disruption of language skills and behavior. This problem makes Lembaga Pendidikan Prananda Bandung (LPAPB) design a graphic media based programs as a strategy to help improve the ability of expressive communication of ASD's children in institutions or at home by using the Home Based Program method, it happens because the children's desire to 
communicate but we find it difficult to understand. In fact, the use of Home Based Programs with this graphic media strategy complained by ASD High Function's children's parents because they consider that is very boring and it is also difficult to make their children focus so that the development of social interaction is hampered. This study aims to identify the needs of ASD High Function's children to learn vocabulary, vocabulary category and stringing words by using Home Based Programs in LPAPB. This design method uses Human Centered Design, Observation, Idea Generation and Test stages that adopt the Double Diamond method with a design extraction tool called the Human Centered Design Toolkit that prioritizes aspects of needs, ability and user behavior as the basic for effective design. The results of this study are lift a flap interactive pictures book as an alternative graphic media with content implementation developing vocabulary capabilities, categorization words set by using home based program. Test results from this study concluded that Interactive lift a flap picture books can be an effective alternative graphic media, as an effort for ASD children's learning media.

Keywords: ASD High Function, home based program, lift a flap interactive pictures books, vocabulary.

\section{PENDAHULUAN}

Autism Spectrum Disorder (ASD) adalah sebuah gangguan psikologi dipicu oleh kelainan syaraf (neuropsychological) yang mempengaruhi kelainan pada perkembangan perpasif otak, secara umum terjadi pada banyak kasus mengakibatkan terganggunya kemampuan komunikasi yang merupakan dasar penting sebagai landasan perkembangan kemampuan anak dalam berinteraksi sosial yang mempengaruhi aspek kemampuan anak ASD dalam berperilaku saat merespon dunia luar (Rahayu, 2014). Autisme berasal dari kata Yunani "autos" yang berarti self (diri) dan isme yang berarti keadaan. Maka autisme dapat diartikan sebagai kondisi seseorang yang terpusat pada dirinya sendiri atau kondisi seseorang yang merasa berada di dalam dunianya sendiri (Budiman, 2002).

Tomchek \& Dunn dalam American Psychiatric Association [APA] (2007), menyatakan bahwa $A S D$ adalah gangguan perkembangan saraf yang ditandai oleh gangguan kualitatif dalam interaksi sosial dan keterampilan komunikasi, bersama dengan pola perilaku berulang dan stereotipik yang terbatas. Wardhani (2009) menggambarkan secara umum mengenai beberapa jenis gejala autisme, yaitu: 
pertama, terganggunya komunikasi pada anak $A S D$ secara verbal dan nonverbal seperti lambat bicara, kesulitan menguasai perbendaharaan kata, pengategorian kosakata dan merangkai kata untuk mengucapkan dan menciptakan bahasanya sendiri yang sulit dimengerti. Juga mengalami echolalia seperti sering meniru dan mengulang kata yang diucapkan orang lain tanpa mengerti maknanya.

Kedua, gangguan dalam interaksi sosial, seperti menghindari kontak mata, tidak melihat jika dipanggil, menolak untuk kontak fisik seperti memeluk, dan lebih suka bermain sendiri. Ketiga, gangguan pada bidang perilaku yang terlihat dan adanya perilaku yang berlebih (excessive) dan kekurangan (defiant), seperti impulsif, hiperaktif, repetitif, namun di lain waktu terkesan memiliki pandangan mata yang kosong, melakukan permainan yang sama dan monoton. Kadang-kadang ada kelekatan pada benda tertentu seperti pada gambar, karet dan lain-lain, yang dibawanya kemana-mana.

Keempat, gangguan pada bidang perasaan/ emosi, seperti kurangnya empati, simpati dan toleransi. Kadang-kadang tertawa dan marah sendiri tanpa sebab yang nyata dan sering mengamuk tanpa kendali bila tidak mendapatkan sesuatu yang tidak ia inginkan. Kelima, gangguan dalam persepsi sensorik seperti mencium-cium atau menggigit mainan atau benda, bila mendengar suara tertentu langsung menutup telinga, tidak menyukai rabaan dan seterusnya.

Gangguan pada anak autis terdapat kelompok ciri-ciri yang disediakan sebagai kriteria untuk mendiagnosa autistik. Hal ini terkenal dengan istilah "Triad of Impairment" yang meliputi tiga gangguan yaitu perilaku, interaksi sosial dan komunikasi (Yuwono, 2012), beberapa gangguan yang menjadi karakteristik dari perilaku ASD pada anak-anak dijabarkan secara ringkas dalam DSM-IV (Diagnostic and Statistical Manual of Mental Disorders IV: pertama, gangguan kualitatif komunikasi di antaranya kemampuan perbendaharaan kosakata tidak 
berkembang atau mengalami keterlambatan; kurangnya kemampuan bermain pura-pura; mengalami echolalia bahasa yang tidak lazim yang selalu diulang-ulang atau stereotipik; penggunaan bahasa stereotip, repetitif (sulit dimengerti).

Gangguan kedua, gangguan kualitatif interaksi sosial di antaranya anak mengalami kegagalan untuk bertatap mata, menunjukkan wajah yang tidak berekspresi; ketidakmampuan untuk secara spontan mencari teman untuk berbagi kesenangan dan melakukan sesuatu bersama-sama; ketidakmampuan anak untuk berempati dan mencoba membaca emosi yang dimunculkan orang lain serta tidak mampu untuk memulai suatu pembicaraan yang melibatkan komunikasi dua arah dengan baik.

Gangguan ketiga, gangguan perilaku di antaranya tidak peduli terhadap lingkungan, bersikap acuh terhadap keadaan sekitarnya dalam keadaan seperti apapun; kelekatan terhadap benda tertentu, munculnya orientasi tinggi terhadap sebuah benda yang sulit dipisahkan hingga masa dewasa; tidak memiliki daya imajinasi yang kuat dalam hal permainan atau cenderung monoton; serta preokupasi pada satu pola terhadap minat tertentu.

\section{Observation}

Seiring meningkatnya populasi anak dengan ASD di Indonesia mengakibatkan pesatnya perkembangan lembaga pendidikan khusus bagi anak $A S D$, pada tahun 2017 yang terdaftar dan tersebar sebanyak 103 tempat di Indonesia (Solek, 2017). Salah satu lembaga yang secara khusus menangani perkembangan anak ASD yaitu Lembaga Pendidikan Autisma Prananda Bandung (LPAPB) yang secara khusus menangani aktivitas pemulihan anak ASD. Mayoritas peserta didik di LPAPB adalah anak ASD High Function dengan permasalahan perkembangan kemampuan bahasa. Anak ASD dengan kategori High Function pada umumnya sudah memiliki kemampuan komunikasi dan berinteraksi namun 
secara pasif. Hal itu teridentifikasi pada lemahnya kemampuan pembendaharaan kosakata, dengan tingkat kesulitan mempelajari kosakata beserta kategorinya dalam tahap dasar, seperti pada kategori kata kerja, kata sifat dan nama benda. Hal tersebut menyebabkan anak ASD High Function kesulitan dalam merangkai kata menjadi sebuah kalimat, sehingga maksud serta keinginannya seringkali sulit dimengerti.

Permasalahan fundamental terhadap anak ASD High Function terkait persoalan tersebut membuat pihak lembaga mengimplementasikan Program Komunikasi Ekspresif untuk dilakukan di rumah yang bernama Home Based Program menggunakan media PECS (Pictures Exchange Communication System) yang merupakan media pembelajaran berbasis gambar. Home Based Program merupakan strategi metode terapi anak $A S D$ yang dikembangkan oleh Patricia Howlin yang merupakan seorang ahli terapi anak ASD pada tahun 1973. Akan tetapi perubahan sikap, pendekatan personal, dan pola didik orang tua sangat menentukan keberhasilan dari metode Home Based Program.

Di lain sisi, pihak lembaga menyatakan terkendala dalam penerapan program tersebut akibat persoalan orang tua anak ASD yang mengeluhkan bahwa anak $A S D$ sulit fokus ketika berlatih dengan media PECS, sedangkan proses pelatihan tersebut sudah dilakukan sesuai dengan prosedur arahan pihak LPAPB. Pihak LPAPB berinisiatif untuk mencari alternatif media grafis pengganti, namun pihaknya tidak membuahkan hasil dengan menyatakan bahwa peredaran media grafis khusus bagi pembelajaran anak ASD masih sulit ditemui di Indonesia. Hasil olah data observasi dan wawancara kepada orang tua dan anak $A S D$, yang secara asumtif mengungkapkan bahwa faktor yang menyebabkan terjadinya hal tersebut adalah adanya rasa bosan anak terhadap pola ajar dan media yang digunakan sama dengan yang diterapkan di LPAPB. Asumsi tersebut disimpulkan oleh orang tua atas dasar inisiatif orang tua bereksperimen untuk mengganti media PECS 
dengan media grafis buku bergambar untuk anak normal ternyata berdampak terhadap perubahan perilaku anak $A S D$, yang menunjukkan ketertarikannya terhadap unsur visual yang terdapat di dalam buku bergambar tersebut.

Orientasi terhadap visual yang tinggi pada anak merupakan sebuah peluang bagi pengembangan media grafis interaktif sebagai sarana alternatif pembelajaran yang dapat mendukung perkembangan pendidikan belajar pada anak (Hodgdon, 2003). Pernyataan tersebut mendukung asumsi penulis mengenai persoalan anak $A S D$ yang membutuhkan alternatif media grafis sebagai sarana pembelajaran pendukung yang dapat menunjang proses terapi di LPAPB untuk mengakselerasikan kemampuan komunikasi ekspresif pada anak ASD High Function secara signifikan. Pemilihan jenis media grafis yang dapat digunakan oleh anak ASD High Function perlu diperhatikan, seperti halnya identifikasi hasil wawancara kepada terapis di LPAPB yang menyatakan bahwa dinilai dari aspek kesehatan dan psikologis.

Salah satu alternatif media grafis yang dapat dijadikan sebagai sarana pendukung pembelajaran bagi anak ASD adalah buku bergambar interaktif (Arie, 2015). Perancangan buku bergambar interaktif sebagai pendukung pembelajaran komunikasi untuk anak ASD melalui penelitian terdahulu yang dilakukan oleh Sari (2015) dan Arie (2015) terbukti efektif. Penelitian tersebut mengungkapkan adanya peningkatan kemampuan komunikasi pada anak ASD setelah diberikan intervensi menggunakan buku bergambar interaktif.

\section{Idea Generation}

Paparan tersebut didukung oleh hasil analisis survey pada terapis dan orang tua anak ASD di LPAPB. Sebanyak $80 \%$ responden menyatakan bahwa jenis media grafis yang sesuai dengan kebutuhan anak ASD sebagai sarana pembelajaran adalah dalam bentuk buku bergambar interaktif lift a flap yang 
memiliki sisi lipatan pada bagian-bagian tertentu sehingga dapat meningkatkan daya tarik dan sistem motorik pada anak ASD lebih baik lagi.

Konsep lift a flap pada buku bergambar dapat merangsang perkembangan motorik pada anak $A S D$, secara interaktif dapat membangun rasa ingin tahu yang tinggi dan dapat melatih kemampuan dalam memecahkan masalah sederhana pada anak $A S D$ sehingga mampu menumbuhkan motivasi belajar yang baik (Long, 2016). Seorang dokter anak ASD bernama Bev Long dari Diagnostic Center Central California, dalam bukunya Using Picture Books to Support the Development of Language in Young Children with Autism menyatakan bahwa buku bergambar merupakan alat yang sangat baik untuk digunakan pada anak dengan $A S D$, sehingga buku bergambar yang secara khusus diperuntukkan bagi anak $A S D$ perlu bersifat interaktif dengan konten kreatif, sederhana dan singkat yang perlu disesuaikan dengan tingkat kemampuan bahasa pada anak ASD.

Jenis lift a flap memiliki manfaat sebagai salah satu sarana yang paling efektif untuk mengembangkan keterampilan verbal, kata-kata dan ilustrasi pada buku bergambar interaktif dapat dipresentasikan sebagai sarana untuk mengembangkan identitas serta perasaan secara individu pada anak $A S D$. Hal ini diharapkan dapat membantu anak ASD dalam mengenal dan memahami budaya, nilai-nilai masyarakat sehingga dapat membantu memahami kondisi lingkungan secara global dalam mengatasi permasalahan yang kompleks di masa yang akan datang (Bianquin \& Sacchi, 2017).

Tujuan penelitian ini adalah untuk merancang buku bergambar interaktif yang dapat memfasilitasi kebutuhan anak ASD High Function dalam mengembangkan kemampuan komunikasi ekspresifnya di LPAPB, sehingga dapat menunjang pembelajaran komunikasinya secara signifikan. 


\section{METODE PERANCANGAN}

Setelah proses pengumpulan data, analisis dilakukan secara terperinci dengan metode Human Centered Design yang digagas oleh Norman (2002), merupakan sebuah rangkaian proses perancangan yang terstruktur dan menitikberatkan kepada pencapaian berupa solusi terhadap kebutuhan, kemampuan serta pola perilaku pengguna sebagai individu ataupun kelompok secara spesifik. Tahap perancangan dengan menggunakan pendekatan Human Centered Design terbagi menjadi empat tahapan yaitu: Observation, Idea Generation (ideation), Prototyping dan Testing (hasil uji coba dalam tahap Testing diuji dengan menggunakan metode Human Centered Design Toolkits: Test Planning, User Journey, dan Test Finding. Tahap Observation yang telah dikemukakan di laman pendahuluan dilanjutkan kepada tahap kedua Idea Generation untuk menentukan fokus masalah yang dirumuskan berdasarkan temuan-temuan yang dihasilkan pada tahap sebelumnya, untuk menghasilkan solusi potensial yang dilanjutkan ke tahap Prototyping.

Proses tahap Prototyping dirumuskan menjadi sebuah draft perancangan untuk mengetahui sejauh mana pengaruh serta efektifitas dari buku bergambar interaktif berjenis lift a flap jika digunakan untuk membantu melatih kemampuan komuniaksi ekspresif pada anak ASD High Function di LPAPB.

\section{Test Planning}

Peserta uji coba adalah lima orang anak ASD High Function di LPAPB dengan rentang usia 4-6 tahun yang berpasangan dengan orang tuanya. Uji coba dilakukan di setiap rumah dari anak ASD High Function dengan waktu yang disesuaikan dengan situasi dan kondisi dari orang tua dan anak ASD menggunakan printed-out prototype dengan bagian konsep lift a flap yang direkatkan secara manual. 
Tahap uji coba pertama langsung memberikan prototipe kepada ibu kemudian meminta ibu dari anak ASD yang bertugas sebagai pendamping untuk mempelajari panduan penggunaan. Setelah itu pengujian langsung yang melibatkan anak dibagi menjadi 4 sesi berdasarkan fase/tahapan dalam penggunaan buku bergambar interaktif tersebut, pengujian pertahap tersebut dibatasi dengan waktu maksimal selama 1 jam/ sesi, guna mengetahui intensitas keberhasilan terhadap penggunaan prototipe tersebut. Seluruh proses pengamatan proses uji coba ini dilakukan dari jarak luar jangkauan partisipan, untuk menghindari rasa intervensi dari peneliti.

\section{HASIL DAN DISKUSI}

\section{Prototyping}

\section{Konsep Dasar Perancangan}

Ide dasar dari perancangan buku bergambar interaktif ini adalah sebuah konsep yang dibuat berdasarkan kebutuhan sarana pembelajaran alternatif tahap dasar untuk membantu anak ASD High Function dalam berlatih kemampuan berkomunikasi ekspresifnya dalam aspek penguasaan kosakata, kategori kosakata dan kemampuan rangkai kata.

Pengguna utama (Primary User) adalah anak ASD High Function di LPAPB, yang pertama kali diketahui melalui situs jejaring sosial. Anak ASD di LPAPB adalah anak yang membutuhkan pelatihan pengembangan kemampuan komunikasi, dikarenakan mereka merasa tidak dimengerti oleh lingkungan sosialnya yang mengakibatkan terganggunya pola perilaku.

Pengguna sekunder (Secondary User) adalah terapis di LPAPB, yang diketahui bahwa mereka adalah personal yang paling memahami karakteristik anak $A S D$. Para terapis berpikir mengenai kebutuhan yang perlu dipenuhi terkait 
permasalahan keterlambatan bahasa pada anak ASD dengan rasa peduli yang tinggi mereka.

\section{Konsep Cerita}

Judul dari buku bergambar interaktif lift a flap ini adalah "Main Yuk!". Pemilihan dan penentuan judul tersebut merupakan hal penting yang bertujuan agar bukan hanya pengguna sekunder yang merupakan buyer dari hasil perancangan ini. Diksi yang digunakan bermakna mengajak dan merupakan rangkaian kalimat pendek dengan kandungan kata tidak baku namun familiar untuk pengguna karena diksi tersebut sesuai dengan bahasa yang digunakan oleh pengguna dalam kesehariannya.

Konsep strategi komunikasi dalam perancangan buku bergambar interaktif lift a flap ini disajikan secara visual yang bertemakan Slice of Life dengan konten non-tekstual, dapat digunakan dengan bantuan seorang pendamping berupa simulasi rangkaian aktivitas interaktif seperti berkunjung, jual beli dan bermain dalam bentuk ilustrasi berupa peta dengan beberapa lokasi sederhana sebagai latar cerita yang dikombinasikan dengan kartu grafis yang merupakan media utama sebagai sarana interaksi sosial. Konsep tersebut digunakan berdasarkan preferensi kegiatan anak $A S D$ terhadap preferensi dalam beraktivitas yaitu berjalan-jalan berkeliling sehingga dipandang familiar.

\section{Konsep Bahasa}

Implementasi diksi pada konten kartu grafis yaitu berupa kosakata dasar dengan bahasa Indonesia yang disesuaikan dengan diksi yang digunakan seharihari yang cenderung tidak baku namun baik dan benar sesuai dengan hasil perolehan observasi. Hal tersebut penting untuk diperkenalkan kepada anak ASD karena anak berpotensi untuk memahami diksi yang serupa digunakan dalam interaksi sosial dalam skala yang lebih besar di lingkungan sekitarnya. 
Kosakata yang digunakan dalam konten kartu grafis merupakan kosakata yang dibagi menjadi lima kategori kosakata dasar yang secara umum digunakan dan ditemui oleh anak $A S D$ sehari-hari, kemudian dibatasi menjadi 10 kosakata per kategori.

\section{Konsep Lift a Flap}

Strategi kreatif yang diimplementasikan pada perancangan buku bergambar interaktif ini yaitu konsep Lift a flap, merupakan pengembangan jenis buku bergambar interaktif yang memiliki daya tarik visual yang menarik perhatian anak untuk berinteraksi secara fisik karena pada objek ilustrasinya terdapat bagian tertutup yang dapat diangkat (buka/ tutup). Pada seluruh lokasi yang merupakan bagian dari ilustrasi peta pada Fase Kosakata, konsep lift a flap diimplementasikan untuk menyembunyikan kartu grafis sebagai konsep interaksi secara fisik.

\section{Penggunaan model karakter}

Model karakter digunakan sebagai pemandu cerita pada fase kosakata menuju lokasi-lokasi pada ilustrasi peta tersebut sebagai sarana simulasi untuk melatih interaksi secara sosial. Melalui model karakter tersebut aspek kebutuhan anak $A S D$ dalam konteks berlatih interaksi secara sosial terpenuhi, dan dipilih berdasarkan kelemahan anak $A S D$ dalam bermain pura-pura.

Adapun prosedur penggunaan dari hasil perancangan tersebut, yaitu sebagai berikut: pertama Fase Pendekatan; tujuannya adalah untuk mengasah ketertarikan, daya ingat dan rasa ingin tahu pada anak ASD. Fase pertama diulangi sebelum masuk kepada fase selanjutnya, sampai anak benar-benar memahami seluruh tahap dalam fase ini. Dengan seiring berkembangnya kemampuan anak dalam menggunakan buku bergambar interaktif ini, maka jumlah objek kartu grafis dapat ditambahkan dan disesuaikan dengan 
kemampuan anak sehingga diharapkan anak dapat semakin meningkatkan kemampuan komunikasi ekspresifnya.

Kedua, Fase Kosakata; melatih daya ingat kosakata, melatih kemampuan kognitif dan kemampuan memecahkan masalah. Ketiga, Fase Kategori Kelompok Kosakata untuk melatih kemampuan anak dalam pengelompokkan kosakata berdasarkan kategorinya dan untuk mengasah daya ingat anak $A S D$ terhadap perbedaan unsur-unsur visual berdasarkan pengategoriannya.

Terakhir, Fase Rangkai Kalimat yang bertujuan untuk melatih kemampuan anak untuk berkomunikasi secara ekspresif mengenai maksud dan keinginannya dalam menyampaikan suatu pesan. Kartu grafis digunakan untuk belajar merangkai kalimat melalui panel dengan tempat kartu grafis pada bagian belakang buku. Fase ini merupakan tahap akhir dalam konten buku bergambar interaktif tersebut, pencapaian pada fase ini merupakan tanda dari keberhasilan atas kemampuan anak melaksanakan fase sebelumnya dengan baik. Seluruh rangkaian fase tersebut dapat diulangi tanpa batas waktu tertentu atas dasar pola bermain sehingga anak dapat menggunakan buku tersebut untuk aktivitas bermain.

\section{Kartu Grafis}

Kartu grafis merupakan alat pengajaran dan media utama yang pertama diakses pada buku bergambar interaktif lift a flap ini. Dibuat dengan ukuran yang disesuaikan dengan daya genggam tangan pengguna utama. Kartu grafis ini terbagi menjadi lima kategori dengan 10 kosakata per kategorinya; sebagai berikut: kata kerja, kata sifat, kata nama binatang, kata nama makanan, dan kata nama buah (Gambar 1). 

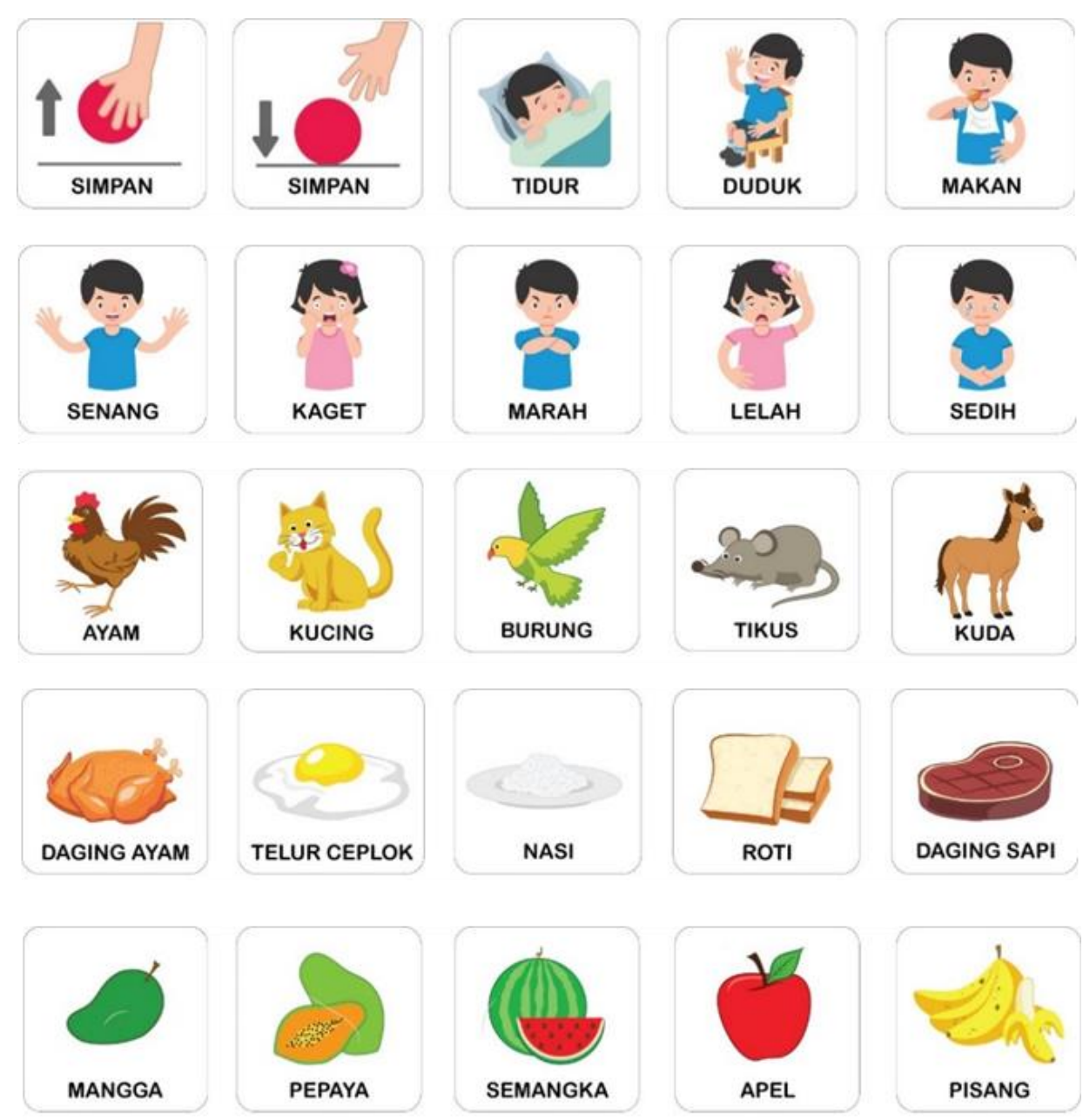

Gambar 1 Kartu Grafis Kata Kerja, Kata Sifat, Kata Nama Binatang, Kata Nama Makanan, Dan Kata Nama Buah

Sumber: Alhamdi, 2018

\section{Model Karakter dan Desain Muka dan Latar}

Gambar 2 berikut merupakan hasil perancangan model karakter serta desain muka dan latar. 

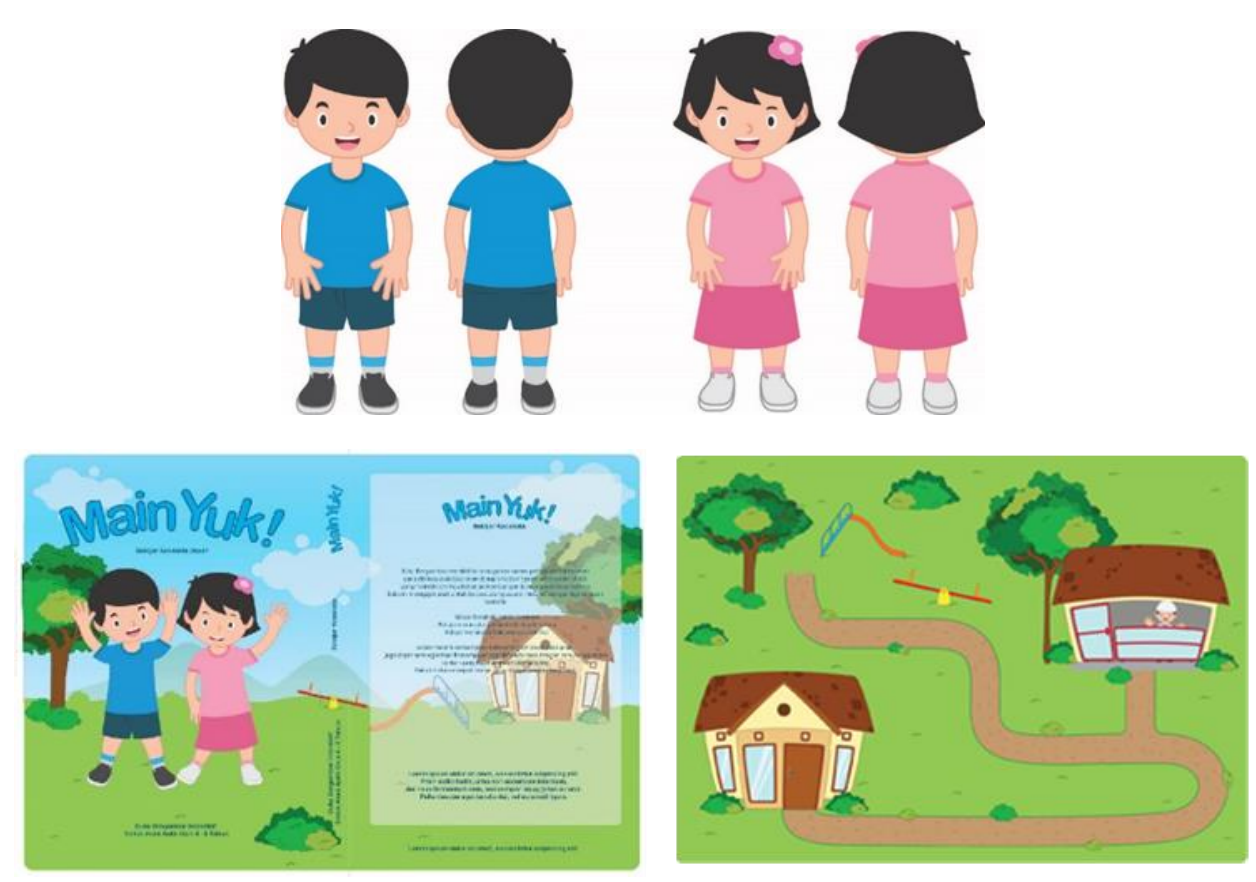

Gambar 2 Model Karakter serta Desain Muka dan Latar

Sumber: Alhamdi, 2018

Test

Setelah dilakukan serangkaian perancangan menggunakan metode perancangan Human Centered Design, model perancangan ini akan diuji cobakan menggunakan metode Human Centered Design Toolkit yakni User Journey, Test Planning dan Test Finding untuk mengetahui hasil yang efektif dan efisien juga secara lengkap melalui metode observasi secara detail dan terperinci kepada pengguna utama (primary user) dan wawancara kepada orang tua (secondary user) dengan menggunakan printed-out paper test untuk mendapatkan umpan balik berupa respon yang dapat memahami aspek kemudahan, kesulitan serta kepuasan secara langsung dari pengguna demi menghasilkan model perancangan yang sangat mendekati kebutuhan pengguna.

Pengujian buku bergambar interaktif "Main Yuk!" dilakukan kepada peserta yaitu lima orang tua anak $A S D$ yang bertugas sebagai pendamping untuk membantu anak mengarahkan dan memberi instruksi kepada anak ASD terkait 
Mohamad Dzikri Alhamdi, Hafiz Aziz Ahmad dan Riama Maslan Sihombing PERANCANGAN BUKU BERGAMBAR INTERAKTIF LIFT A FLAP UNTUK MEMBANTU KETERLAMBATAN WICARA ANAK ASD (AUTISM SPECTRUM DISORDER) DI RUMAH 1 - 20

penggunaan buku bergambar interaktif tersebut. Wawancara hanya dapat dilakukan kepada orang tua karena faktor terkait keterlambatan perkembangan pada anak ASD Figh Function di usia 4-6 tahun, namun dilakukan observasi untuk mengetahui objektivitas pada penggunaan terhadap anak ASD.

\section{a. User Journey}

Tindakan dilakukan untuk mengukur peningkatan kemampuan komunikasi ekspresif (gestur dan verbal), dengan langkah sebagai berikut: pendamping mempelajari penggunaan, memilih kartu grafis, berinteraksi dengan bermain dalam halaman peta, mengacak lalu meletakkan kartu grafis pada kolom kelompok kosakata dan diakhiri dengan merangkai kata.

Perasaan Partisipan; pertama, pendamping mempelajari penggunaan (wawancara). Tahap awal ini menyatakan bahwa tiga orang partisipan merasakan bahwa panduan penggunaan mudah dimengerti, dua orang menyatakan panduan penggunaan kebingungan pada aspek susunan redaksi. Selanjutnya, Anak ASD memilih kartu grafis (observasi). Satu orang anak ASD terlihat cukup lama dalam merespon sekitar 30 menit yang selama itu anak bertindak preokupasi menetap (tidur di lantai dan menggerakkan tangan seperti burung secara simultan). Empat orang anak $A S D$ membutuhkan waktu dengan rata-rata waktu 20 menit untuk merespon kartu grafis.

Namun keseluruhan anak ASD merespon dengan baik dengan prompt pendamping namun dengan mimik wajah datar terhadap kartu grafis yang diberikan. Tiga anak menemukan objek kesukaannya yaitu ayam, eskrim dan permen, sedangkan dua anak tidak menemukan objek yang senanginya yaitu coklat dan mobil-mobilan namun tidak menolak ketika diberikan objek pengganti yaitu coklat diganti dengan es krim lalu mobil-mobilan diganti dengan jeruk. 
Kemudian anak $A S D$ berinteraksi dengan bermain dalam halaman peta. Seluruh anak membutuhkan waktu lama (15-20 menit) untuk mau memegang model karakter sebagai pemandu dalam peta. Satu anak langsung merespon dengan membuka bagian tertutup halaman dan terlihat senang ketika menemukan kartu dengan secara verbal namun tak bermakna. Dua anak sempat kebingungan namun dalam waktu kurang lebih 5 menit anak mampu merespon bagian penutup, dengan satu anak $A S D$ tersenyum simpul dan satu anak $A S D$ terlihat datar. Dua anak kebingungan dalam waktu relatif lama (20-15 menit) sebelum merespon bagian penutup; namun keduanya terlihat senang.

Dalam tahap ini, dua anak membutuhkan waktu 2-3 hari dan tiga anak membutuhkan waktu sehari untuk dapat menggunakan media ini dengan mudah. Anak selalu membutuhkan prompt verbal dan gestur mulut pendamping untuk mengenali objek pada kartu grafis. Seluruh anak kesulitan mengenali objek alat permainan yang terdapat pada lokasi taman.

Langkah selanjutnya, anak $A S D$ mengacak lalu meletakkan kartu grafis pada kolom kelompok kosakata. Tiga anak dapat mengikuti dan fokus proses ketika pendamping ketika menyusun kosakata berdasarkan pengelompokannya dengan baik, dan dua orang terdistraksi oleh audio dari luar ruangan. Dua anak enggan mengacak kartu grafis, dan tiga anak mau mengacak kartu grafis. Satu anak mau meletakkan kembali seluruh kartu grafis, dua anak hanya mau meletakkan satu dan tiga kartu grafis. Dua anak enggan meletakkan kartu grafis. Seluruh anak masih kebingungan mengenai pencocokan dua perbandingan kategori yang dilipih oleh pendamping berdasarkan objek kesukaannya, dengan perolehan waktu yang lama (rata-rata satu jam). Dua anak lain kesulitan mengenali ilustrasi buah naga, satu orang kesulitan mengenali objek susu, seluruhnya kebingungan dengan objek nasi (pilihan kategori makanan). Membutuhkan waktu 2-3 hari sampai anak benarbenar dapat melakukan tahap ini dengan baik. 
Tahap berikutnya, anak $A S D$ merangkai kata. Seluruh anak $A S D$ membutuhkan waktu rata-rata 30-45 menit untuk dapat menyusun sebuah kata dengan meletakkan kartu melalui prompt pendamping. Seluruh anak ASD masih membutuhkan prompt dalam menggunakan kartu grafis (mau/ tidak). Satu orang anak enggan merespon, satu anak mampu merespon secara verbal namun tak bermakna dan gestur (tangan menunjuk) kearah kartu. Tiga anak ASD mampu melakukan respon gestur (tangan menunjuk) ke arah kartu.

Dugaan Partisipan: seluruh orang tua memiliki hipotesis yang serupa dengan hipotesis peneliti, bahwa media ini dapat membantu mengembangkan kemampuan komunikasi ekspresif pada anak ASD High Function di LPAPB. Touchpoints melalui LPAPB. Adapun peluang sebagai berikut: materi perlu dipermudah sehingga memungkinkan anak untuk merespon dengan lebih efisien; perlu diperbaiki dalam aspek konten berupa redaksi panduan penggunaan; pemilihan kata dan pengilustrasiannya perlu diperjelas lagi; serta harus memperhitungkan ukuran buku dan kartu grafis sehingga sesuai dengan kebutuhan serta kemampuan pengguna sekunder.

\section{b. Test Finding}

Seluruh anak dapat menggunakan desain prototype melalui intervensi yang dilakukan oleh pendamping dengan cukup baik dengan keberhasilan merespon komunikasi ekspresif secara gestur dan verbal walaupun masih belum bermakna, namun masih banyak ditemukan kendala pada aspek desain, materi serta media untuk diperbaiki pada prototipe ini.

Seluruh orang tua menyatakan bahwa media ini cocok digunakan sebagai media grafis alternatif, dan penambahan halaman peta karena anak menyukai dan senang. Tiga orang tua menyatakan ilustrasinya bagus dan menarik perhatian anak. Satu orang tua menyatakan ukuran kartu grafis kurang besar. Dua orang 
menyatakan bahwa ukuran buku terlalu besar sehingga sulit menyimpannya dan beranggapan akan terlalu berat jika diimplementasikan pada material yang sebenarnya.

Hal yang dapat bekerja dengan baik pada rangkaian desain prototype tersebut adalah media buku bergambar interaktif dan struktur penggunaan yang dapat dipahami orang tua dan dilakukan oleh anak dengan mudah. Partisipan mencoba untuk memperkirakan berat dari buku dan pendekatkan kartu ke dekat mulut anak atas kekhawatirannya tertelan.

Berdasarkan hasil uji coba model perancangan melalui desain prototype yang telah dilaksanakan, maka dapat disimpulkan bahwa partisipan masih menemukan berbagai kendala. Namun mayoritas partisian merespon desain prototype tersebut dengan cukup baik sehingga dalam konteks secara menyeluruh, kehadiran dari buku bergambar interaktif lift a flap ini cukup efektif. Hal itu terbukti menjawab asumsi penelitian ini, bahwa buku bergambar interaktif efektif untuk menunjang anak $A S D$ dalam melatih perkembangan kemampuan komunikasi ekspresif secara gestur dan verbal walaupun masih belum bermakna. Dalam penelitian ini, masih banyak ditemukan kendala pada aspek desain, materi, serta media untuk diperbaiki pada prototipe ini. Untuk mengetahui respon verbal kosakata secara jelas dan spesifik, maka diperlukan waktu uji coba yang lebih lama.

\section{Kesimpulan}

Berdasarkan asumsi dari penelitian, paparan perolehan data serta dukungan literatur yang telah dianalisis dan kemudian menghasilkan sebuah model perancangan yang telah diuji cobakan; maka dapat disimpulkan bahwa atas terganggunya perkembangan kemampuan bahasa anak ASD High Function teridentifikasi pada lemahnya penguasaan kosakata, pengategorian kosakata 
serta kemampuannya untuk merangkai kata menjadi kalimat dan trauma terhadap pola ajar metodis. Untuk itu diperlukan konsep interaktif berupa lift a flap dan konten Halaman Peta, Halaman Rangkai Kelompok Kosakata dan Halaman Rangkai Kalimat untuk memenuhi kebutuhan anak $A S D$ dalam berlatih kemampuan komunikasi ekspresifnya menggunakan lima kategori kosakata tingkat dasar yaitu Kata Kerja, Kata Sifat, Kata Nama Hewan, Kata Nama Makanan dan Kata Nama Buah. Maka perancangan media grafis alternatif dibuat dalam bentuk buku bergambar interaktif Lift a Flap yang dikombinasikan dengan kartu grafis.

Secara keseluruhan perancangan buku bergambar interaktif lift a flap ini merupakan media grafis cetak dua dimensi (2D) yang secara khusus dirancang sesuai dengan kebutuhan pengguna yaitu anak ASD High Function usia 4-6 tahun di LPAPB. Buku bergambar tersebut dapat menjadi sarana interaksi dan sarana pembelajaran yang menampilkan unsur grafis sesuai dengan preferensi anak $A S D$ terhadap bentuk dasar yang membulat (rounded). Selain itu, buku gambar tersebut menghindari bentuk sudut meruncing, warna hijau dan biru yang dominan namun notasi warna belum diketahui secara spesifik, di mana pola bermain di lantai dan berjalan-jalan mengelilingi sebuah area tertentu anak $A S D$ tentunya berbeda dengan anak normal yang seusianya. Maka dari itu, implementasinya dapat menjadi solusi pada perkembangan kemampuan bahasa anak ASD di Indonesia atas sulitnya memperoleh media grafis khusus perkembangan bahasa anak ASD sehingga dapat membantu menekan tingkat populasi penyandang $A S D$ di Indonesia.

\section{DAFTAR PUSTAKA}

Bianquin, N., Sacchi, F., 2017. More Than Just Pictures. Inggris: Universita Della Valle d'Aosta.

Budiman, M., 2002. Strategi Visual Mengatasi Masalah Perilaku dan Masalah Komunikasi Anak Autis. Jakarta: Autisma Indonesia. 
Hodgdon, L., 2003. Proccessing Visual Stimuli. Los Angles: Autism Learning Center.

Long, L. C., 2016. Disability Rights Education \& Defense Fund. San Francisco: Southeastern Louisiana University.

Lusiati, A., 2015. Perancangan Buku Cerita Bergambar untuk Anak Autis. Surabaya: Universitas Negeri Sebelas Maret.

Norman, D., 2002. The Design of Everyday Things. Revised \& Expanded Edition. New York: Persues Books Group.

Sari, D.Y.P., 2015. Pembelajaran Remedial terhadap Kemampuan Menulis Permulaan Anak Autis. Jurnal Pendidikan Khusus, 7 (3). Tersedia di $<$ https://jurnalmahasiswa.unesa.ac.id/index.php/jurnal-pendidikankhusus/article/view/12597> [15/10/18, 15.30 WIB]

Rahayu, S.M., 2014. Deteksi dan Intervensi Dini Pada Anak Autis. Jurnal Pendidikan Anak, 3 (1), hh. 420-428. Tersedia di <https://doi.org/10.21831/jpa.v3i1.2900> [15/10/18, 15.35 WIB]

Solek, P., 2017. Pengembangan Kecakapan Komunikasi Anak ASD. Yogyakarta: CV Andi Offset.

Tomchek, S. dan Dunn, W., 2007. Sensory Processing in Children With and Without Autism. Louisville: American Psychiatric Association

Wardhani, Y.F., 2009. Autisme, Terapi Medis Alternatif. Yogyakarta: Anggrek.

Yuwon, J., 2012. Memahami Anak Autistik; Kajian Teoritik dan Empirik. Bandung: Alfabeta. 